\title{
ANALISIS RESPON SISWA TERHADAP MEDIA ANIMASI POWERPOINT POKOK BAHASAN KALOR
}

\author{
${ }^{1)}$ Devi Nanda Efendi , 2) Bambang Supriadi , 2)Lailatul Nuraini \\ ${ }^{1)}$ Program Studi Pendidikan Fisika FKIP Universitas Jember \\ Email devinanda1998@gmail.com
}

\begin{abstract}
Online learning is one form of adaptation in the field of education to the face of the covid 19 pandemic. Existing technology continues to be developed for both online meeting needs and digital learning media that was suitable to support distance learning systems. One of the lessons that is considered to be lacking in utilizing digital learning media is physics. The purpose of this study was to analyze the responses of Tanggul 1 Senior student after using physics learning media in the form of an animation media. The research method used as descriptive. The respondents of this research were students of grade XI MIPA 1 SMA Negeri 1 Tanggul consisting of 32 students. This research uses data retrieval techniques through student response questionnaires consisting of aspects of operation/use of media and the user reaction. The results of the students' response analysis to the use of powerPoint animation media amounted to $81,33 \%$ with details on each aspect was $81,41 \%$ on the aspect of media use and a score of $81,25 \%$ on the aspect of usage reaction. Based on the results of the research that has been done, it can be stated that the powerPoint animation media of the subject of heat received a very positive response from the respondents.
\end{abstract}

Key word: Heat, powerPoint animation media, response

\section{PENDAHULUAN}

Pesatnya perkembangan ilmu pengetahuan dan teknologi, menuntut tenaga pendidik untuk melakukan usaha pemanfaatan teknologi dalam proses belajar mengajar. Usaha yang dapat dilakukan dengan mengkombinasikan proses belajar mengajar dengan teknologi salah satunya yaitu mengembangkan media pembelajaran. Pembelajaran dengan menggunakan teknologi berpengaruh terhadap hasil belajar siswa (Sakat et al., 2012). Pengembangan media pembelajaran dengan menggunakan teknologi biasa disebut dengan multimedia. Multimedia adalah proses pembelajaran yang melibatkan indera dan organ tubuh manusia (Munadi, 2008).
Pada multimedia, media dikombinasikan dengan berbagai macam teks, grafik, animasi, suara dan video supaya media yang menjadi menarik (Arsyad, 2002). Multimedia yang dibuat menarik dapat meningkatkan pemahaman dan respon mahasiswa (Nuraini \& Supriadi, 2018). Pengembangan media pembelajaran yang dikembangkan dalam media pembelajaran ada 2 macam yaitu berupa software dan hardware, namun media pembelajaran yang dikembangkan pada penelitian ini berupa softwarenya saja. Software yang digunakan untuk pengembangan media pembelajaran adalah Microsoft PowerPoint.

Microsoft PowerPoint adalah program aplikasi presentasi yang digunakan untuk membuat slide presentasi yang menarik dan profesional dengan efek transisi dan animasi 
(Permana, B., \& Pratita, 2019). Kelebihan dari penggunaan Microsoft PowerPoint yaitu penyajian slide pada powerPoint dapat dibuat sangat menarik, isi dari slide powerPoint dapat dijadikan animasi, sehingga dapat meningkatkan motivasi belajar siswa (Daryanto, 2016). Pengembangan media pembelajaran powerPoint ini nantinya akan mengkombinasikan teks, grafik, suara, dan video. Penambahan efek transisi dan animasi pada media menjadikan media yang dikembangkan beranimasi. Media pembelajaran yang dikembangkan bersifat interaktif sehingga membuat pembelajaran menjadi efektif dan efisien (Sanaky, 2019). Hal ini terbukti dari hasil penelitian pelaksanaan ujian berbasis online yang melibatkan siswa secara aktif dalam mengerjakan soal direspon baik/positif oleh siswa (Anggraeni \& Nuraini, 2020).

Media pembelajaran dikembangkan pada materi kalor. Kalor adalah energi panas yang berpindah dari benda yang bersuhu tinggi ke benda yang bersuhu lebih rendah (Giancoli, 2001). Satuan internasional kalor adalah joule. Pada kalor terdapat tiga cara energi panas berpindah dari benda bersuhu tinggi ke benda bersuhu lebih rendah yaitu dengan cara konduksi, konveksi, dan radiasi.

Pemilihan materi kalor ini dikarenakan pada materi ini siswa kesulitan dalam memahami materi, sehingga dengan menggunakan bantuan dari media animasi powerPoint diharapkan dapat memudahkan siswa dalam memahami materi kalor dan lebih memotivasi siswa dalam proses pembelajaran. Motivasi siswa dapat dilihat dari respon siswa selama proses pembelajaran. Respon adalah suatu rangsangan/tanggapan siswa setelah diberikan suatu media (Maharani \& Widhiasih, 2016). Respon siswa dalam pembelajaran sangat penting, karena dari respon, guru dapat mengarahkan cara berfikir siswa menjadi lebih baik dan benar.

\begin{abstract}
Berdasarkan uraian latar belakang, peneliti terdorong untuk melakukan penelitian tentang analisis respon siswa terhadap media animasi powerPoint pokok bahasan kalor. Tujuan dari penelitian ini untuk menganalisis respon siswa terhadap penggunaan media animasi powerPoint.
\end{abstract}

\section{METODE}

Penelitian ini menggunakan jenis penelitian deskriptif, dengan tujuan untuk mendeskripsikan dan menganalisis respon siswa dalam media animasi powerPoint. Penelitian dilakukan di SMA Negeri 1 Tanggul pada siswa kelas XI MIPA 1. Teknik pengumpulan data menggunakan angket, angket adalah sebuah pertanyaan yang disusun secara logis yang sehubungan dengan permasalahan penelitian (Rahayu, 2009). Angket diberikan kepada siswa setelah siswa menggunakan media pembelajaran yang dikembangkan. Angket diberikan kepada siswa dengan menggunakan google form, hal ini dikarenakan pandemi Covid 19 sehingga tidak memungkinkan untuk melaksanakan penelitian secara tatap muka.

Pedoman analisis yang digunakan pada angket yaitu menggunakan skala likert. Adapun pedoman skala likert pada angket dapat dilihat pada Tabel 1 .

Tabel 1. Pedoman Skor Penilaian

\begin{tabular}{cc}
\hline Skor & Keterangan \\
\hline $\mathbf{5}$ & Sangat Setuju \\
$\mathbf{4}$ & Setuju \\
$\mathbf{3}$ & Kurang Setuju \\
$\mathbf{2}$ & Tidak Setuju \\
$\mathbf{1}$ & Sangat Tidak Setuju \\
\hline
\end{tabular}

(Sugiyono, 2015)

Persentase respon siswa dapat dihitung dengan menggunakan rumus:

$$
P=\frac{\Sigma x}{\Sigma i} \times 100 \%
$$

(Agustina, 2015) 
Keterangan :

$$
\begin{array}{ll}
\mathrm{P}= & \text { Presentase } \\
\Sigma \mathrm{x} & =\begin{array}{l}
\text { Jumlah keseluruhan jawaban } \\
\text { responden dalam seluruh item }
\end{array} \\
\Sigma \mathrm{i} & =\begin{array}{l}
\text { Jumlah keseluruhan skor ideal } \\
\text { dalam per item }
\end{array}
\end{array}
$$

Untuk mengetahui hasil analisis

respon siswa dengan menggunakan kriteria respon siswa pada Tabel 2 .

Tabel 2. Kriteria Respon Siswa

\begin{tabular}{cc}
\hline $\begin{array}{c}\text { Interval Respon } \\
\text { Siswa }\end{array}$ & Kriteria \\
\hline $80 \% \leq \mathrm{Na}<100 \%$ & Sangat Positif \\
$60 \% \leq \mathrm{Na}<80 \%$ & Positif \\
$40 \% \leq \mathrm{Na}<60 \%$ & Cukup Positif \\
$20 \% \leq \mathrm{Na}<40 \%$ & Kurang Positif \\
$\mathrm{Na}<20 \%$ & Sangat Kurang Positif \\
\hline & (Arikunto, 2010)
\end{tabular}

\section{HASIL DAN PEMBAHASAN}

Penelitian yang dilaksanakan pada bulan Desember 2020 sampai Januari 2021 di SMA Negeri 1 Tanggul Kelas XI MIPA 1 dengan responden sebanyak 32 bertujuan untuk mengetahui respon siswa terhadap penggunaan media animasi powerPoint pokok bahasan kalor. Prosedur penelitian dilakukan dengan cara menjelaskan secara singkat langkah-langkah dalam penelitian dan cara penggunaan media animasi powerPoint. Selanjutnya media animasi powerPoint yang dikembangkan diberikan kepada siswa, kemudian siswa diminta untuk mengisi angket respon terhadap penggunaan media animasi powerPoint. Aspek penilaian respon siswa terdiri dari aspek

\begin{tabular}{|c|c|c|}
\hline Aspek & Hasil & Kriteria \\
\hline $\begin{array}{l}\text { Pengoperasian/penggun } \\
\text { aan media }\end{array}$ & $81,41 \%$ & $\begin{array}{l}\text { Sangat } \\
\text { Positif }\end{array}$ \\
\hline Reaksi Pemakaian & $81,25 \%$ & $\begin{array}{l}\text { Sangat } \\
\text { Positif }\end{array}$ \\
\hline Rata-rata & $81,33 \%$ & $\begin{array}{l}\text { Sangat } \\
\text { Positif }\end{array}$ \\
\hline
\end{tabular}
pengoperasian/penggunaan media dan reaksi pemakaian. Hasil rekapitulasi respon siswa dapat dilihat pada Tabel 3.
Tabel 3. Hasil Respon Siswa

bahwa respon siswa terhadap penggunaan media animasi powerPoint pokok bahasan kalor sebesar $81,33 \%$ jika dilihat pada kriteria respon siswa pada tabel 2 , maka hasil respon siswa dinyatakan sangat positif. Hasil dari aspek pengoperasian penggunaan media sebesar $81,41 \%$ dengan kriteria sangat positif, artinya sistem pengoperasian media animasi powerPoint yang dikembangkan mudah digunakan, sehingga membuat siswa merasa senang dalam menggunakannya. Penggunan multimedia dalam proses pembelajaran sangat mengapresiasi siswa dan guru karena dengan menggunakn multimedia, pembelajaran menjadi menyenangkan (Hadijah, 2018). Penggunaan media pembelajaran animasi powerPoint dapat membuat siswa semangat dan termotivasi dalam proses belajar mengajar, sehingga dapat menghilangkan rasa bosan siswa dalam mengikuti pembelajaran. Hal ini sesuai dengan hasil penelitian sebelumnya yang menyatakan bahwa penggunaan multimedia dalam pembelajaran dapat meningkatkan ketertarikan siswa dalam proses belajar dan dapat menghasilkan hasil belajar yang baik dari sebelumnya (Sajid \& Hassan, 2013).

Hasil dari aspek reaksi pemakaian media animasi powerPoint sebesar $81,25 \%$ dengan kategori sangat positif. Dari hasil aspek reaksi pemakaian meunyatakan bahwa materi yang dijelaskan pada media sudah jelas mudah dipahami, sehingga hasil belajar yang didapatkan siswa lebih baik dari sebelumnya. Hal ini sesuai dengan penelitian sebelumnya yang menyatakan penggunaan media animasi powerPoint mempunyai 
dampak yang signifikan pada hasil belajar siswa (Rahman \& Mahmud, 2018).

\section{SIMPULAN}

Hasil rata-rata dari analisis respon siswa terhadap media animasi powerPoint pokok bahasan kalor sebesar $81,33 \%$ dengan kriteria sangat positif. Hasil dari respon setiap aspek pada pengoperasian /penggunaan media sebesar $81,41 \%$ dengan kriteria sangat positif dan aspek reaksi pemakaian sebesar 81,25 dengan kriteria sangat positif. Penggunaan media animasi powerPoint dalam pembelajaran memberikan respon sangat positif kepada siswa.

\section{DAFTAR PUSTAKA}

Agustina. (2015). Media dan Pembelajaran. Palembang: Universitas Sriwijaya.

Anggraeni, F. K. A., \& Nuraini, L. (2020). Analisis Respon Mahasiswa Pendidikan Fisika Terhadap Computer Based Testing Pada Mata Kuliah Manajemen Lab. Jurnal Pembelajaran Fisika, 9(3), 101-106.

Arikunto, S. (2010). Prosedur Penelitian Suatu Pendekatan Praktik. Jakarta: Rineka Cipta.

Arsyad, A. (2002). Media Pembelajaran. Jakarta: Rajawali.

Daryanto. (2016). Media Pembelajaran. Jakarta: Rineka Cipta.

Giancoli, D. C. (2001). Fisika Jilid 2: Physics Fifth Edition. Jakarta: Erlangga.

Hadijah, S. (2018). Analisis Respon Siswa dan Guru Terhadap Penggunaan Multimedia Interaktif Dalam Proses Pembelajaran Matematika. Jurnal Numeracy, 5(2), 176-183.
Maharani, A. A. P., \& Widhiasih, L. K. S. (2016). Respon Siswa Terhadap Umpan Balik Guru Saat Pelajaran Bahasa Inggris Di SD Saraswati 5 Denpasar. Jurnal Bakti Saraswati, 5(2), 20882149.

Munadi, Y. (2008). Media Pembelajaran, Sebuah Pendekatan Baru. Jakarta: Gaung Persada Press.

Nuraini, L., \& Supriadi, B. (2018). Analisis Pemanfaatan Multimedia Terhadap Penguasaan Konsep Reaksi Nuklir Mahasiswa Pada Mata Kuliah Fisika Inti. Saintifika, 20(2), 22-31.

Permana, B., \& Pratita, B. G. (2019). 36 Jam Belajar Komputer Microsoft PowerPoint 2019. Jakarta: Elek Media Komputindo.

Rahayu, M. (2009). Bahasa Indonesia di Perguruan Tinggi. Jakarta: PT Gramedia Widiasrana Indonesia.

Rahman, M., \& Mahmud, N. (2018). Pengaruh Penggunaan Media Pembelajaran PowerPoint Terhadap Hasil Belajar Matematika Peserta Didik Kelas X SMA Negeri 3 Majene. Saintifik, 4(1), 83-92.

Sajid, A. R., \& Hassan, T. U. (2013). ICTs in learning: Problems faced by Pakistan. Journal of Research \& Reflections in Education (JRRE), 7(1), 52-64.

Sakat, A. A., Zin, M. Z. M., Muhamad, R., Ahmad, A., Ahmad, N. A., \& Kasmo, M. A. (2012). Educational Technology Media Method in Teaching and Learning Progress. American Journal of Applied Sciences, 9(6), 874-878.

Sanaky, A. H. H. (2019). Media Pembelajaran. Yogyakarta: Safiria Insania Press. 
Sugiyono. (2015). Metode Penelitian Pendidikan (Pendekatan Kuantitatif, Kualitatif, dan R\&D). Bandung: Alfabeta. 